A close examination was made of a glacier tongue $1000 \mathrm{ft} .(305 \mathrm{~m}$.) above the East African Mountaineering Club hut at Bujuku. This flows down from Mt. Speke. Here we were joined by Messrs. O. K. Mather and G. Du Bois of the Geological Survey, who by permission of its Director, Dr. K. A. Davies, were enabled to visit this area and map the tongue (see Fig. 2, p. $5^{\text {II }}$ ).

A beacon was set up so that annual measurements may be made. The glacier snout lies at about $14,000 \mathrm{ft}$. $(4267 \mathrm{~m}$.) in a deep gulley whose smooth sides display an obvious and rapid retreat. Vegetation has not yet sprung up in the abandoned area which extends to an altitude of 13,000 ft. (3962 m.).

Large areas were devoid of firn and showed layers of dirty ice, the dirt probably consisting of wind-blown dust and the ash from the innumerable forest fires which are lit in the valleys every hot season. Only a few stones were held in the ice and there is no moraine at the present glacier foot although a fairly large one exists $500 \mathrm{ft}$. $\left(1_{52} \mathrm{~m}\right.$.) lower down. Still lower very large ancient moraires are in evidence.

I was able to crawl right under and inside the ice at the centre of the snout. There were no signs of plucking of the rock bed. The roof of this ice cave was $5 \mathrm{ft}$. ( $(\mathrm{r} \cdot 5 \mathrm{~m}$.) above me with corrugations transverse to the line of flow at $4 \mathrm{ft}$. intervals. The crystals here measured up to $3.0 \times 0.5 \mathrm{~cm}$. and there seemed to be a tendency for them to lie vertical to the line of flow. At the side of the tongue they were smaller (about $1.0 \mathrm{~cm} . \times 2 \mathrm{~mm}$.) and I had the impression that they lay more or less parallel to the line of flow. There were bands of smaller crystals and their significance is obscure. They cannot be annual bands as there is no distinct winter-summer cycle.

Access to, and examination of, the Elena Glacier was difficult because of ice falling from the hanging glacier above it. The snout could not be reached, but beacons were set up for annual measurements. These may be found by bearing $195^{\circ}$ from Ridge Camp and walking for fifteen minutes. The snout of this glacier terminates at $14,800 \mathrm{ft}$. ( $45 \mathrm{II} \mathrm{m}$.) in a deep unvegetated groove. There is no terminal moraine and its stream is clear of detritus. This is true of all the Ruwenzori glacier streams and one never sees the turbid, opaque water common to alpine streams of similar type.

At some $200 \mathrm{ft}$. (6I m.) above the snout I entered a cleft by a rock outcrop. I found only dense, consolidated firn. The crystals were of millimetre size. Ablation caused bands to stand out like fins of an air-cooled cylinder. They contained much dirt but again only of such size as could be wind-blown. Again there was no evidence of plucking of the rock bed and no boulders or detritus could be seen in the snout of this glacier.

I could find no true glacier ice above the snout nor any sign of present glacial action, and this would seem to show that the conditions now existing are not quite usual. Investigation should be continued at other times of year and more frequently. Valuable work could be performed by a properly equipped party camping on the Stanley Plateau and working over a much longer period than was possible for us.

MS. received 8 May $195^{\circ}$

\title{
THE LARSEN SHELF ICE
}

Discussion of the paper by Mr. D. Mason read at a Meeting of the Society on 77 November 1949. (Fournal of Glaciology, Vol. I, No. 8, 1950, p. 409-13.)

The Chairman (Professor Gordon Manley) opened the meeting for discussion.

Professor S. E. Hollingworth (University College, London) raised the question of the terminology of the various types of shelf ice and expressed the hope that at this stage of their investigation names and definitions should be descriptive rather than general. 
Dr. B. B. Roberts (Senior Research Fellow, Scott Polar Research Institute, Cambridge) dwelt on this subject at some length.*

The Bishop of Portsmouth (The Right Reverend W. L. S. Fleming) congratulated Mr. Mason on his paper, and hoped that he would, in time, make available a chart marking the positions of the various areas of the shelf ice which he described and also the positions and heights of places where altitudes had been measured and where special structures had been seen. $\mathrm{He}$ wondered whether there was any similarity between the lenticular depressions found by Mr. Mason and the larger "ice calderas" which were seen by the British Graham Land Expedition of 1934-37 during the journey down King George VI Sound. The character and origin of these features appeared to be quite different, but he wondered if the structures which Mr. Mason had mentioned had raised rims.

Mr. D. Mason said that the lenticular holes referred to by Knowles lay along longitudinal cracks in what was probably glacier ice. This merged imperceptibly into what was undoubtedly shelf ice farther east and the exact junction could not be determined. The holes were almost certainly formed by the collapse of snow bridges.

Mr. W. H. WARD (Building Research Station, Watford) asked whether the precipitation decreased southwards along the east coast of Graham Land and whether the tidal range varied along the coast.

Mr. MASON said that no information was available for precipitation on the east coast of Graham Land (and south of Hope Bay), apart from Nordenskjöld's records at Snow Hill Island which covered only one season. During his (the speaker's) journey they had much less snow than was expected. Comparing notes with the party from Hope Bay, who were travelling at the same time over the northern portion of the Larsen Shelf Ice, his (the speaker's) party had much less than they had, but perhaps this was just by good fortune.

Dr. RoBerts said that there was no information about the tidal range along the east coast of Graham Land.

Mr. L. C. W. Bonacina said he thought the problem of precipitation in Antarctica was very much complicated by the drifting. He wondered whether shelf ice was nourished partly from drifting as well as from falling snow. At any rate he would like to ask whether any definite relation had been found between the configuration of the shelf ice in the Weddell Sea and that in the Ross Sea and the direction of snow transporting winds. He thought there was no doubt that the southern end of the Weddell Sea would afford a better test case than the northern, with which Mr. Mason's paper mainly dealt.

Mr. G. DE Q. RoBIN (Falkland Islands Dependencies Survey) said that the main snow-bearing winds in Graham Land were westerly. The tendency for heavy snowdrifts to form to the leeward (eastward) of the steep sliffs of the northern sector of Mr. Mason's journey would not be so marked further south, where the coastline rose more gradually. This difference in precipitation and surface wind force during westerly winds might therefore account for the shelf ice being much thicker in the north.

Mr. W. H. WARD said that it was not essential to postulate snowfall in the north, in the lee of the higher mountains, being spread over a great area; even snowfall of greater intensity, close in the lee of the hills, might be sufficient to produce a wider and more static shelf of ice.

The Chairman suggested that in the ice of steep cliffs and slopes of the land there might be considerable accumulation which would help to explain the relatively steep seaward slope of the ice. Presumably precipitation with westerly winds would be greater to the northward, in which

- Comments on the terminology of shelf or barrier ice as put forward by Dr. Roberts and Mr. Wordie (see Vol. $r$, No. 8 , p. $4^{1} 3^{-19}$ ) have been held over. $-E d$. 
event the seaward slope of the shelf ice would be much more gentle in higher latitudes; much would depend on the dominant wind and of this he knew little. It was somewhat risky for one who had not been there to make statements with regard to the climate of Graham Land in the absence of extensive published observations. Yet he found it difficult to resist the conclusion that precipitation must decrease quite rapidly with increased latitude. The best thing to do was to take the map and invert it, when north Graham Land was seen to bear an evident analogy with south-west Greenland, and the region from Joinville Island to James Ross Island would broadly resemble that around Torgilsbu (lat. $6 \mathrm{I}^{\circ} \mathrm{N}$.) east of Cape Farewell where, under rather warmer conditions, annual precipitation was about 80 in. (2000 mm.). On both coasts of Greenland precipitation fell off with distance from an open sea and was of the order of 10 in. $\left(25^{\circ} \mathrm{mm}\right.$.) in lat. $70^{\circ} \mathrm{N}$.

In Graham Land the broad extent of ice in the western Weddell Sea should likewise be associated with a considerable southward decrease of precipitation, although in some measure offset by the relatively narrow mountain axis and the more open sea to the north-west.

Estimates of quantity were thus very risky as probably no one knew the average breadth of the winter ice west of Graham Land in say lat. $65^{\circ} \mathrm{S}$. But it seemed likely that along the mountainous coast in lats. $68-70^{\circ} \mathrm{S}$. the annual precipitation (as water) would not exceed half that in lat. $63^{\circ} \mathrm{S}$. and might be still less.

Mr. A. Stephenson (Imperial College of Science and Technology, University of London) said that even if it were assumed that land formations to some extent caused the greater height of the shelf ice to the north, he agreed that precipitation was greater in the north and was probably a very considerable contributory factor. He said that in those areas where the Larsen Shelf Ice was three and four hundred feet above sea-level he did not think that it was therefore three or four hundred feet thick. He wished to know what evidence there was for the possibility of there being a belt of low foothills at the base of the steep cliffs which were shown in the slides. If the cliffs went straight down into the sea then the shelf ice must be floating, and one would therefore not expect large undulations on its surface. Since these undulations did exist, he thought there might be considerable areas of low-lying ground, or off-shore islands, supporting the ice cover. In those conditions shelf ice and piedmont ice must mix and be indistinguishable from each other. This raised another difficulty which he wished members would consider when defining shelf icenamely its portrayal on maps. "Relic ice," piedmont ice and shelf ice all adjoined each other at times, and he wondered if, in those circumstances, the landward limit of the shelf ice could be delineated. He doubted it. Relic ice could really be ignored, as in most cases it was a relic of previous sheets of shelf ice and should therefore be included in that category.

Mr. MAson, commenting on the questions and statements of Mr. Bonacina and Mr. Stephenson, said that he thought that too much emphasis had been laid on the effect of the high rock cliffs of northern Graham Land forming heavy snowdrifts to the east during the westerly winds; such an effect was local, and could hardly affect a roo mile wide belt of shelf ice. The precipitation certainly increased to the north, and this undoubtedly in part caused the increased thickness of the Shelf. But he did not think that this was the main cause of the persistence of the shelf ice on this part of the coast. Mr. Stephenson was probably very near the mark in suggesting that there might be low-lying land or off-shore islands under the ice; it was a pity that no party had yet been able to spend a considerable time on the Larsen Shelf Ice, travelling eastwards to its seaward edge and determining levels as accurately as possible, and looking tor evidence of islands. He thought that possibly, south of Heard Island (see map Vol. I, No. 8, p. 4II), the sea deepened more rapidly with distance from the coast than it did farther north, thus reducing the tendency of thick shelf ice to form; in shallow areas, for instance between Steele Island and the mainland, thick shelf ice had formed and still persisted. It was probably aground in this area, since just south of Steele Island a tide crack running in an east-west direction had been found; there had 
also been a rather abrupt change in levels-from $90 \mathrm{ft}$. above sea-level to about $\mathrm{I}_{5} \mathrm{ft}$. Another contributory factor to the failure of thick shelf ice to form along the southern part of the coast may have teen the east to west current which flowed around the shores of the Antarctic continent. The rather sudden change in direction of the coast at Nantucket Inlet (see map) would cause an increase in the speed of the current up this part of the coast, reducing the ability of thick sea ice to form. This effect could be seen off New Bedford Inlet in December 1947, when there was a narrow belt of new sea ice along the edge of the shelf ice, then a belt of open water about a quarter of a mile wide, and then rough, hummocky close pack with many bergs.

Dr. H. F. P. Herdman ("Discovery" Investigations Committee) asked if Mr. Mason had observed any "black ice" in the course of his travels on the Larsen Barrier, that is to say icebergs or shelf ice which had either a black band, or signs of imprisoned ash or scoriae.

Mr. MASON said that there were no signs of volcanic activity, either of recent or earlier occurrence, and no bands of imprisoned ash visible in shear faces; such would be more likely to be found farther north, in the neighbourhood of Robertson Island (lat. $65^{\circ} \mathrm{S}$.)

Dr. N. A. Mackintosh (Director of Research, "Discovery" Investigations Committee) said that the Weddell Sea shelf ice, as a whole, was interesting because of the numerous icebergs seen in regions to the north-east. These had presumably drifted out of the Weddell Sea. Some of them were very large. They could scarcely have calved from the Larsen Shelf Ice since the edge of the latter seemed to have changed little, if at all, in the last fifty years. The Filchner Shelf Ice seemed the more likely origin.

J. M. Wordie (Chairman, Scott Polar Research Institute, Cambridge ; communicated) : I very much regret not having been able to attend Mr. Mason's paper. It is the first description in any detail of the shelf ice fringe along the east coast of Graham Land. Nordenskjöld's journey in October 1902 provided much less information. Mr. Mason's observations are therefore of very great interest and should go a long way towards a proper knowledge of this interesting feature. I should like to say how much I appreciate his work and the numerous and careful observations which he made during the course of his journey. He has indicated how difficult it is to obtain accurate measurements of height when depending only on barometric observations, but no other method seems possible at this stage. The wide differences in height from place to place show how important it is to have exact figures. I notice, for instance, that some of the ice which he crossed has almost certainly been sea ice, perhaps less than a year in age. In December 1893 Larsen described fjords spreading through the ice barrier which he had discovered, and perhaps the low levels recorded by Mr. Mason are simply frozen inlets which may be the same as Larsen's fjords. There is still a great deal to discover, such as the extent to which land glaciers penetrate the ice, and whether it is terraced in such a way as to indicate successive breakings off and reformations. Is the failure to confirm Nordenskjöld's lower and upper ice terraces due to this? I also have the idea that the ice may be disappearing more rapidly than it re-forms and that it may not be long before a barrier shelf such as this ceases to be a single connected feature, as has apparently already occurred for a similar formation on the west coast of Graham Land near the mouth of King George VI Sound.

Mr. MASON (communicated): Larsen's fjords are probably comparable to the rifts seen just south of Hearst Island. I do not think, though, that any of the ice we crossed was as little as one year old, except possibly near Cape Boggs; this young ice did not cover an extensive area, and its junction with thicker ice was not clearly evident. In few places were "terraces," such as Nordenskjöld described, apparent, and these were generally drifted up so that no difficulty was encountered in traversing them with sledges. 